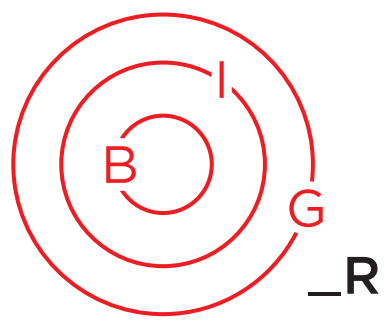

ESSAY

SPECIAL ISSUE

\title{
"Return of Mental Borders": A Diary of COVID-19 Closures between Kehl, Germany, and Strasbourg, France
}

\author{
Birte Wassenberg *
}

This paper retraces the author's personal experience of the COVID-19 lockdown from March to July 2020 at the Franco-German border from a threefold perspective: that of a cross-border worker living in Kehl, Germany, and working in Strasbourg, France; that of a Franco-German citizen with a family and children of both French and German nationality; and that of a researcher specialized in border studies. The paper deals with national re-bordering policies and their direct personal and psychological consequences for borderlanders, and also questions whether such measures are adequate to contain the pandemic, especially in a context of European Union integration which is based on the principle of a "Europe without borders".

\section{Introduction}

The border between Strasbourg, France, and Kehl, Germany, has often been hailed as a best-practice model for the implementation of a "Europe without borders" (Wassenberg and Brunet-Jailly 2020, 24). France and

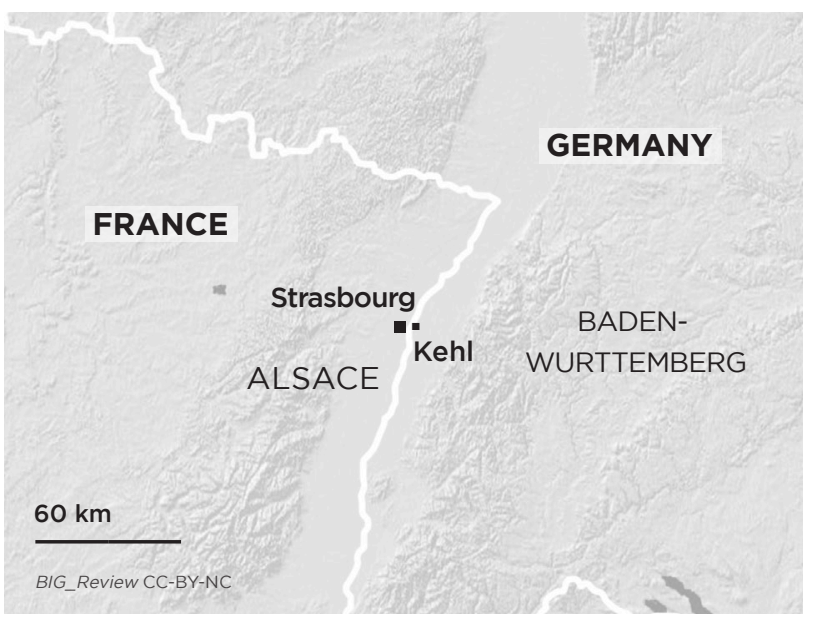

Germany are part of the Schengen Area, which encompasses 26 European countries that mutually eliminated border controls on the movement of people between them beginning in 1995. The cross-border region of Strasbourg-Kehl/Ortenau was designated a Eurodistrict in 2004, one of the first integrated cross-border living spaces with funding and administrative support from the European Union (EU). There are four bridges crossing the Rhine River, which traces the border in this region: one for cars, one for trains, a "friendship bridge" for pedestrians and cyclists, and most recently, a Tramway (Denni 2008).

Free circulation is therefore not only guaranteed for goods but also for citizens, and the border is normally invisible and not an obstacle to mobility in any way. Therefore, a closure of the border and the re-introduction of border controls disrupts the integrated space, creating almost a shock for local populations and raising questions about the ideal of a "Europe without borders" (Wassenberg 2020a, 30).

\footnotetext{
* Birte Wassenberg, PhD, is Professor in Contemporary History at the Institute for Political Studies (Sciences Po), University of Strasbourg, France. Contact: Birte.wassenberg@unistra.fr
} 


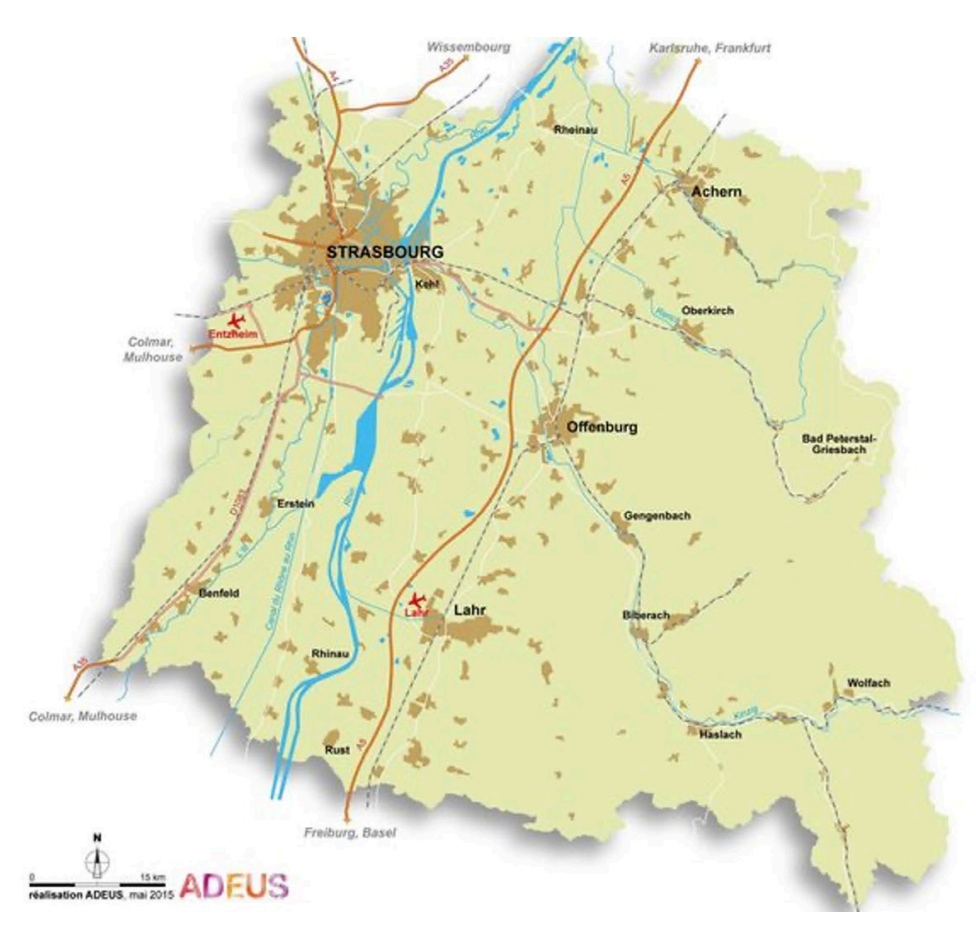

Figure 1. Map: The Eurodistrict Strasbourg-Ortenau. Source: Adeus, Landratsamt Ortenau, 2015.

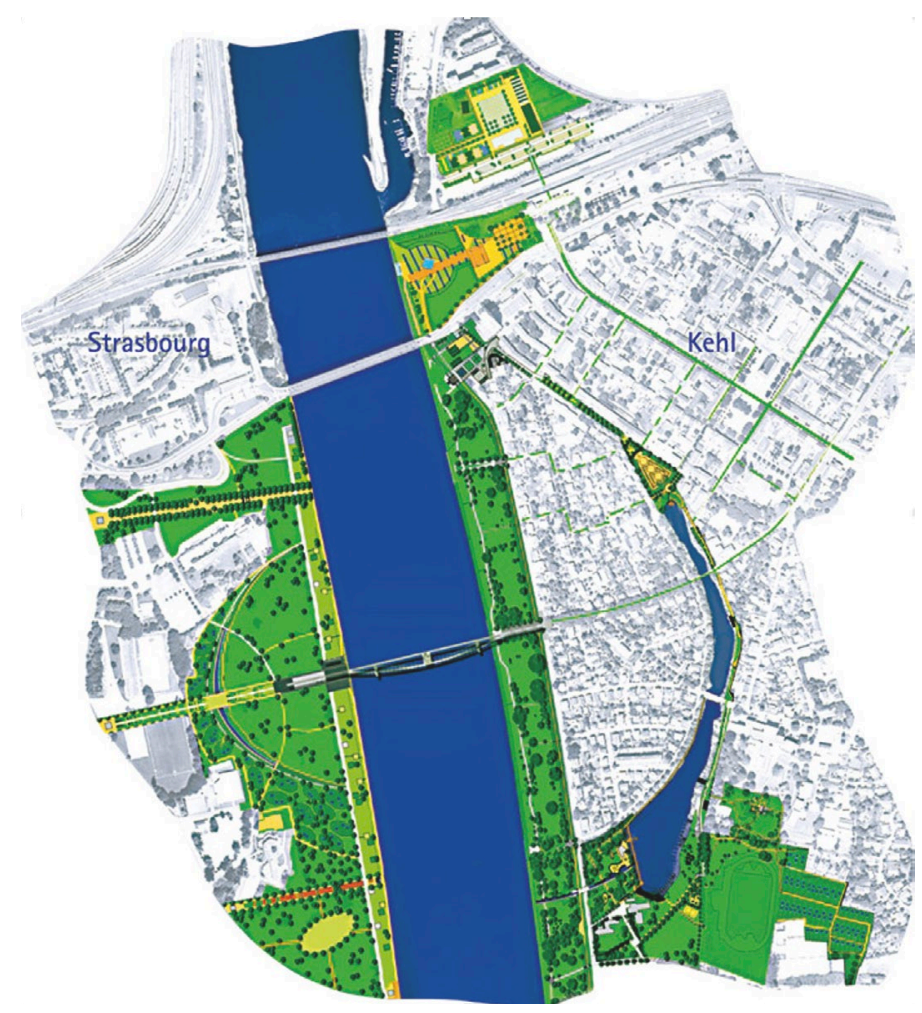

Figure 2. Map: The Garden of the Two Rivers. Source: bwgründe, 2004. The 4th bridge (Tramway) is not shown as it was only finished in 2016.
The COVID-19 crisis in spring 2020 was not the first time this happened. In fact, following the migration crisis of 2015, re-bordering policies were already introduced by many European Union (EU) Member States in order to stop the massive inflow of refugees, not only creating problems for migrants to enter the EU, but also for the internal border flows of cross-border workers, for instance at the Franco-German border. The Westphalian function of the border which seemed to have disappeared between Strasbourg and Kehl suddenly resurfaced (Berrod 2020, 53). During the COVID-19 crisis, this Westphalian re-bordering effect was more severe, as the closure was complete: all four crossings between Strasbourg and Kehl were closed hermetically for the population on each side of the border. This meant that freedom of movement for European citizens was suspended until the border was re-opened progressively in June 2020. In my experience of the crisis, it became clear that, indeed, "the freedom of movement of the European citizen remains defined largely within the conceptual framework of borders" (Bouveresse 2020, 64). When the border closes, mobility ends, and, as a borderlander, my life as a European citizen, navigating daily between France and Germany, also ends.

This personal diary retraces how I experienced the COVID-19 crisis from a threefold perspective: that of a cross-border worker living in Kehl and working as a French civil servant at the University of Strasbourg (Sciences Po); that of a Franco-German citizen with a family and children of both French and German nationality; and that of a researcher specialized in border studies (Wassenberg 2020b). ${ }^{1}$ As the diary shows, it was not a slow process and as many other borderlanders, I was unprepared. Each day brought with it new events and new shocks from the arrival of the crisis to the lockdown and even the de-confinement came suddenly, like startling from a nightmare...

\section{Mid-March 2020: The Arrival of the Crisis}

March 11: My German colleague, Professor Joachim Beck, president of the Hochschule Kehl, calls me from his office in Kehl at $1 \mathrm{pm}$ and informs me that the German Robert Koch Institute-which is the competent national scientific research office in the Federal Republic of Germany concerning the pandemic COVID-19-has classified the French region Alsace, in which Strasbourg is the major urban centre, as a high risk zone. On the French side, nobody knows about it. At Sciences Po, there is business as usual and university courses are being held according to the normal schedule, whereas the Hochschule Kehl is being closed immediately (Beck 2020). 
March 12, morning: I arrive at $9 \mathrm{am}$ at the Château Pourtalès to give my course for the Study Abroad CEPA program, and my American students come to see me to announce they cannot attend my class: they are packing to immediately return to the United States on order from their universities. Everybody is in a panic, as American President Donald Trump decided overnight to close US borders for travelers from the EU (BBC News 2020). I can no longer maintain my course; students are running away. That's when I realize something exceptional is happening. It is now certain that I can no longer organize my conference on the border migration crisis, which is supposed to take place on March 16 in the Château Pourtalès, together with my European and American students-what an irony! I have to cancel everything and all I can do at that moment is go home to my house in Kehl by crossing the border as usual, without any border checks...

March 12, evening: at home, my colleague Joachim Beck calls me to tell me that authorities are apparently going to close the border, based on firsthand information from the Staatsministerium (State Government) in Baden-Wurttemberg. I realize with shock that my elder daughter and one of my twins are with me at home in Kehl, but that my son and the other twin are on the French side of the border. My colleague reassures me at first, but five minutes later, he calls back to tell me that he changed his mind: "If I were you, I would try to fetch the other twin quickly-you never know what might happen". But this is impossible; it was too late, for she is already on a train heading towards a village in the north of Alsace in order to rejoin a friend of hers. That is when my elder daughter says to me: "Mum, this is just as in August 1961 when they constructed the wall of Berlin, we have half of the family on this side of the border and the other half on the other side of the iron curtain". In the end, that evening, they do not close the border. Maybe my colleague was overreacting, and the borders will stay open?

March 15, evening: French President Emmanuel Macron addresses the French people. During his speech, he repeatedly uses the expression "we are at war!" It is frightening. He announces immediate confinement for the entire French population (Macron 2020).

March 16, morning: Finally, it was the German government who closed the border overnight, without any coordination with its French neighbour. In fact, nobody was informed in the border region (Berrod, Chovet, \& Wassenberg 2020). Now, in Kehl, all four bridges are closed. There are no longer any trains, cars, trams, or people crossing the border. It is a saddening and almost spooky experience. I remember that the last time I crossed the border was Friday the 13th, probably a bad sign if I were superstitious ...
March 18: German Chancellor Angela Merkel addresses the German people. She is brief. "This is a historic task-and it can only be mastered if we face it together" is her message. She says she is sorry that now German grandparents can no longer see their grandchildren, as it is too dangerous. She asks Germans to be reasonable and to stay at home. She begs them, but she does not order them (Merkel 2020). The two speeches by the heads of state of France and Germany could hardly have been more different.

March 16-22: Germany imposes a "Kontaksperre" (a barrier to contact) but this is not labelled a confinement. Furthermore, every German Land (state) adopts different rules. In Bavaria, it is close to total confinement. In North-Rhine Westphalia, there is no restriction to free movement at all. Between these two extremes, anything is possible in the 16 German Länder (states): there are interdictions on meeting with as many as two, three, four, or five people, depending on the Land, and many people cannot understand what is happening. There is mention of a German federal "Flickenteppich" (Patchwork). At least, the federal government finished by deciding after a week that the barrier to contact was to be applied on the whole territory of Germany-but this was the only measure made uniform in the Federal Republic during the pandemic. It seems evident: just as the two addresses to the nation, the measures in Germany and France to combat the pandemic posed a stark contrast as well. Indeed, in centralized France, the general confinement was announced by Macron from 17th of March onwards and stayed in place until 11th of May for all French people, whether they lived in the much affected regions of Alsace or Paris or in the almost completely COVID-19 free regions of Bretagne (Berrod, Chovet, \& Wassenberg 2020). The border between France and Germany stays closed and I am trapped on the German side.

\section{Mid-March through May: The "Lockdown"}

March 16 onwards: In Kehl, the general atmosphere changes completely. No more French cars and no more French people in the streets. Kehl becomes a small German village again.

March 18: Healthcare in Alsace is a disaster: hospitals are at their limits of accepting patients needing ventilators, and patient "triage" has started as not everyone can obtain intensive care. This reminds me of Marcon's war rhetoric. The French government seeks solutions. Opening border crossings to relieve pressure does not seem to be likely. In Mulhouse, the French army starts a complex and costly operation of flying out patients by helicopter to Toulon and Marseille on the French Mediterranean coast (20 minutes 2020). 
March 21: There seems to be small hope for crossborder Franco-German cooperation: our Land of Baden-Wurttemberg, adjoining Alsace, has started to take on patients from the French border region. In Freiburg, the first French patients arrive (eurojournalist 2020).

March 27: Strikingly, French national logic of dealing with the crisis and assuring health security for the population still seems to outweigh the prospective benefits of cross-border health cooperation: from Strasbourg, a TGV jet transports 48 COVID-19 patients to Marseille which is 1000 kilometres away, whereas in neighboring German communities across the river, there are empty beds in hospitals and German partners willing to welcome French patients... (Le Parisien 2020).

April 21: It is my son's birthday and we have had enough of being separated by the border, so we decide that he will try to cross it. He has in his

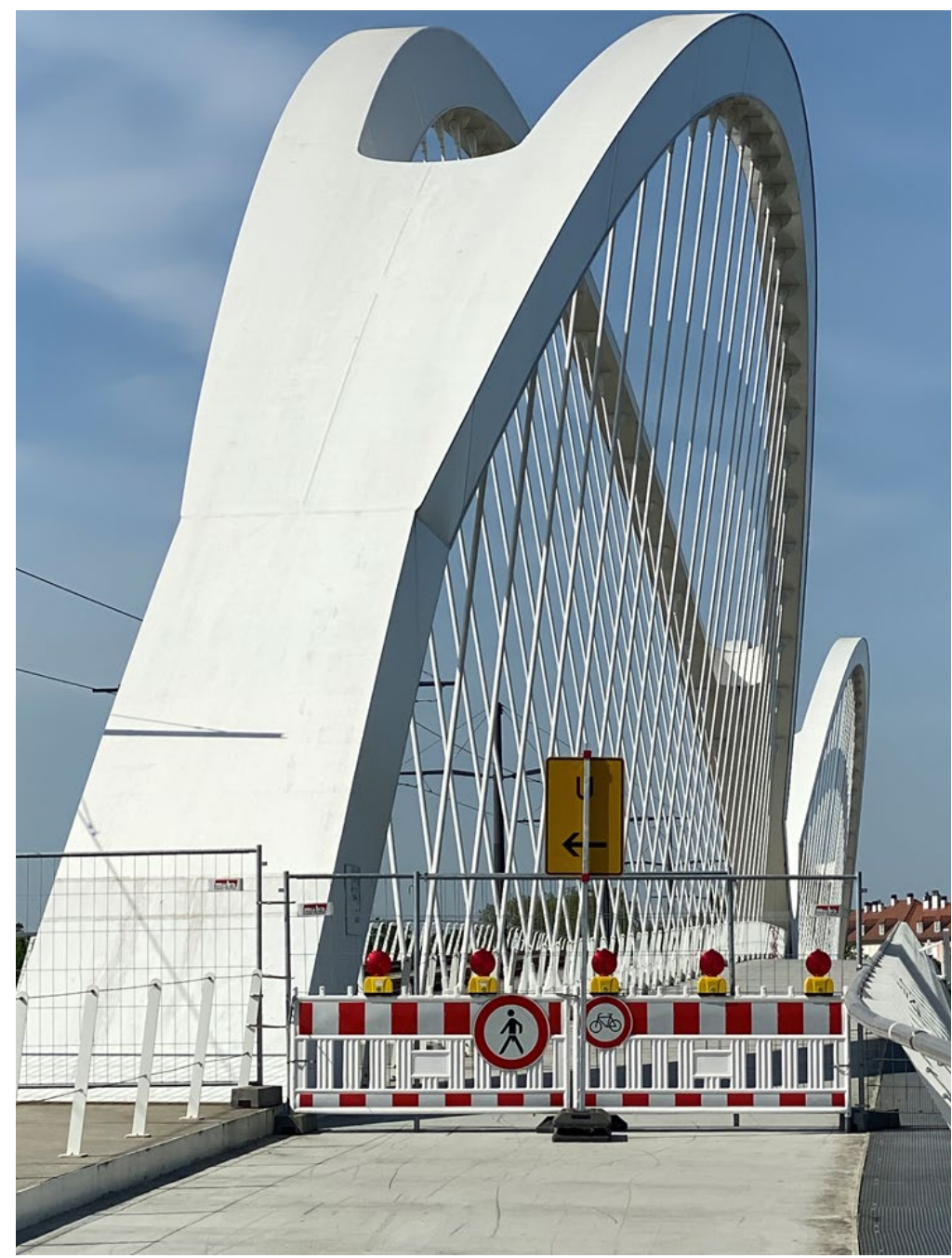

Figure 3. Tram bridge, Strasbourg-Kehl. Photo taken by the author, April 24, 2020, from the German side. The bridge is used for the cross-border tramway and for cyclists and pedestrians; the barriers prevent passage by bike or on foot. possession an authorization allowing him free circulation in Strasbourg as a Medical Science Student to present to the border guards on the French side and a German passport to present to the border guards on the German side. We are not sure if the French border guards will accept his exception document to cross, but they do. Interestingly, the paper also serves at the French border as a passport to re-enter Strasbourg from the German side, although borders are not mentioned anywhere in the text. More alarming, neither at the French nor the German border are health protocols employed: there is no check of temperature, no proof of negative COVID-19 tests to be shown. When my son arrives at the German border in Kehl, the magic key to enter was not his medical function nor his true purpose of visiting his mother and sisters, but rather his nationality. Upon "Your ID please!" he showed his proof of German nationality and it opened the way. "Ah you are German! Of course, then you can pass"! the border guard exclaimed. If he had shown his French passport the passage would not likely have been possible. I say to my son, not without irony: "Of course, certainly, the virus must be French!" (Berrod, Chovet, \& Wassenberg 2020).

April 24: I no longer cross the border. In fact, I no longer go there at all and have not even seen it. However, once, I do meet a friend at the border who needs to have her car repaired in a garage in Kehl. With an authorization paper from the garage, she is allowed to cross the border and it is easy. Again: no use of any health protocols on either side of the border. But the French father of my twins has no authorization to come to Kehl to visit his daughters. It is not considered a "sufficient reason" to go to the other side. This management of the border appears to me more and more absurd. That day, I see this border, with barriers everywhere, policemen, border guards. I keep my distance. I take photos. I am at the same time scared and sad. This closed border makes me cry. Not only I live in-between two national systems, have two nationalities, and work in France. On top of this, my research on crossborder cooperation and European Integration had always shown this Franco-German space one of contact, exchange and integration. This seems finished and over now. It has become a place of separation and distance. 
May 9: On this European Day, in honour of Robert Schuman's 1950 Declaration of Europe's first common market, there are many micro-demonstrations at European borders calling for a de-bordering and the return of the spirit of a Europe without borders. At the border between Strasbourg and Kehl, the French and German border population walk alongside the two riverbanks of the "Garden of the two rivers" and wave umbrellas as a sign of the Franco-German friendship (DNA 2020). The mood starts to change. The border residents show signs of rebellion against closed borders (Dreosto 2020).

May 30: The "rebels" walk from each side of the friendship bridge to meet. They climb over the barriers, despite and against all rules and interdictions. To underline this revolutionary spirit, Kai Littmann, journalist of the Eurojournalist(e) later qualified this in one of his articles as the "prise de la passerelle" (the seizure of the passage)-an allusion to the storming of the Bastille (Boucart 2020). Personally, I still keep my distance from the border. It is no longer part of my daily life; I have become a Franco-German captured on the German side of the border.

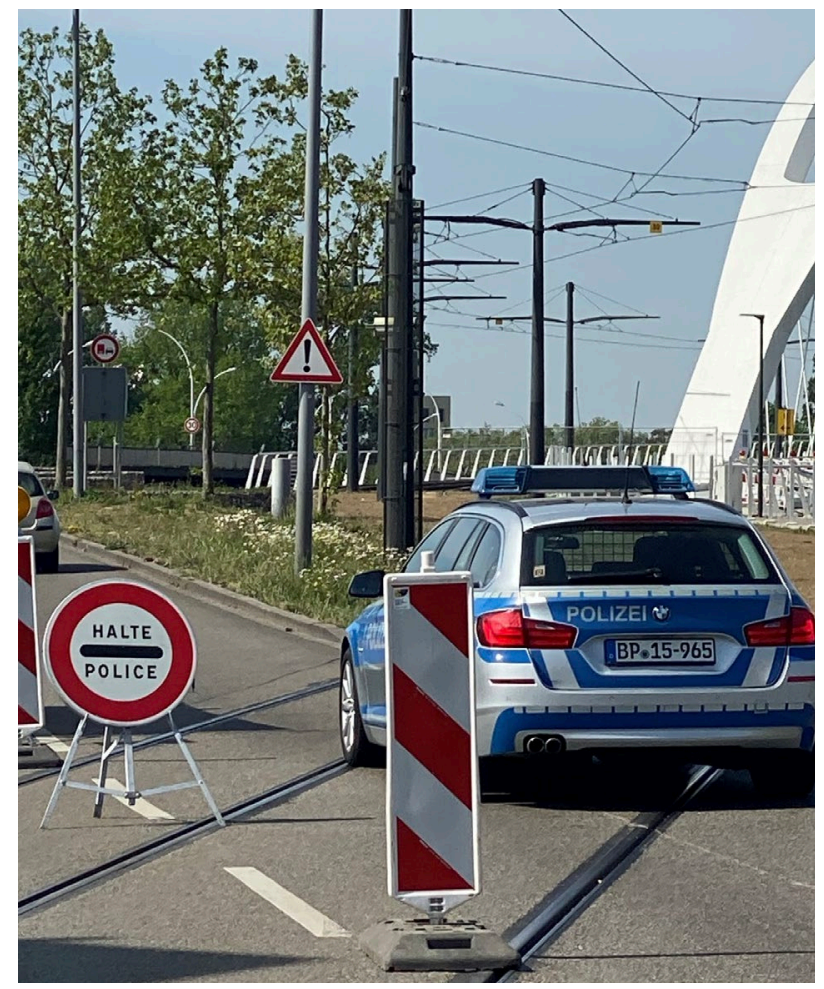

Figure 4: Car passage, Strasbourg-Kehl. Photo by the author, April 24, 2020, from German side. The bridge is used for car-crossing, the passage restricted to one line, with a new 'halte/police' sign and each car is stopped and checked by police officers. However, the photo shows a German police car driving across to the French side, suggesting the absurdity of suspending all civilian circulation while police cooperation continues, under which police vehicles based within 30 kilometres of the line are authorized to pass to the neighbors' side.

\section{Late May tomid-June:The De-confinement}

May 23: I start again to cross the border, armed with my authorization as a cross-border worker signed by the president of the university of Strasbourg. But the border guards on the French side seem to not understand anything. They only stop cars with a German matriculation plate, therefore of course also mine. "Do you live in France?" they ask. "No, in Germany", I reply. "But why then do you want to go to France?" is the second question. "I work there at the University" is my second reply. They insist: "But you are German!!" It is almost a reproach. I start to get angry: "Yes and I am also French!" There is a moment of silence, as they have to take this in. They are confused, because they cannot put me in a German or a French box and they don't know what else they can say to harass me. Finally they find how to trap me: "But today it's Saturday, what do you want at the university?" They have no right whatsoever to ask that question, but I am still proud to spontaneously come up with this rather ironic reply: "Monsieur, researchers at the university have no fixed working hours. They in fact work all the time". They are so surprised that they give in: "Okay, you can pass then" (Wassenberg 2020b). The passages at the border are different each time and on each side of the border. On the French side, sometimes I manage to pass without any explanation and without showing any ID, sometimes there is not even a border guard present, but at other times I have to explain lengthily up to a quarter of an hour my precise reasons to cross the border. On the German side, there are also controls, but everything is different and the questions are never the same as on the French side. In my case, the German matriculation plate of my car and especially my German passport are like magic keys: I always pass. Only one time, a young German border guard asks me a lot of questions when I pass for a second time in the same day. I tell her: "But you are still here? You have been working more than 12 hours!" She admits that this is true, that she is working far away from her family, that this is not her usual workplace and they have all had enough of this. "We will be glad when all these controls are over!" is her conclusion. This border crossing is indeed tiring for everyone. In fact, my daily passages during this transition period reveal to me the twofold character of the border: France-Germany on the one hand and Germany-France on the other, for each national public authority applies their own rules and their own management of the border (Wassenberg 2020b).

June 15: It is over. The barriers have been lifted. The border is open (Les Echos 2020). No more border guards. It is like nothing has ever happened, as if one wakes up from a bad dream and realizes that everything is back to normal. There are only the photos from confinement to prove the border was ever closed, so closed that it made me cry. 


\section{Conclusion}

The closure of the border was used by the national authorities in France and in Germany as a measure to contain the COVID-19 pandemic. But territorial governance was not considered from a "bottom-up" governance approach. Consulting neither the local nor regional authorities nor the borderlanders, this re-bordering policy was part of the general lockdown implemented more or less stringently from March to June $2 \mathrm{O} 2 \mathrm{O}$ by the national governments of most EU Member States in order to stop the exponential spread of the virus. Whereas social distancing and reduced movement of people may indeed help to avoid the uncontrolled spread of the pandemic, the border closure was operated with regard to the limits of the nation-state rather than those of areas contaminated by the virus. Nor was there, at least concerning the border between France and Germany, any specific health protocol applied in order to check border-crossers with regard medical criteria, such as measuring temperature or requiring a negative COVID-19 test. This led to the false conclusion that the virus could be associated with a "nationality" and stopped at the national border. What then emerged were new forms of nationalism and so, in Strasbourg and in Kehl, the borderlanders were stuck in the middle of this national re-bordering.

What was most worrying about the lockdown during the COVID-19 crisis was not so much the different approaches to the crisis management by the French and German public authorities, nor their non-coordination of bordering and de-bordering, but rather the psychological consequences of the process of re-bordering on the border population. It led to a return of mental borders long thought forgotten and even overcome which were being drawn along national lines. This could already be observed during the migration crisis in 2015, when the massive inflow of refugees into the EU caused problems of migrant integration and new waves of nationalism and xenophobia, also in France and in Germany (Bartel, Delcroix, \& Pape 2020; Beaupré \& Fischer 2020). The aggression was then turned against the migrant, whereas during the COVID-19 pandemic, it affected the mutual perception of French and Germans living at the border, recreating mistrust and resentment where the reconciliation process has normally led to understanding and friendship. The crisis finally brought with it to the surface a political discourse reduced to the national border lines without any consideration of a multi-level approach to border identity in Europe which embraces the local, regional, national, and European level. The re-bordering processes were taking place without any consideration of the border people living in these areas which, since the 1950s, have become more and more closely integrated cross-border spaces. The danger of this national rescaling is to recall into question the very founding principles of the European Union which was based on a unification of the European people and not on their national differentiation.
However, during the lockdown, there were also signs of rebellion of the borderlanders against this re-bordering and re-nationalization process: the inhabitants of Strasbourg and Kehl thus called for a reopening of the border which shows that European Integration and Franco-German reconciliation is resilient. And, after the lockdown, when free circulation at the border was re-established, the national authorities in France and Germany seem to have learned a lesson as they started to cooperate in order to determine rules of local or regional containment with regard to health criteria, i.e. the numbers of COVID-19 cases in an area, instead of with regard to national borders. So far, the border between Strasbourg and Kehl has therefore not been closed again.

\section{Note}

1 The research methodology of this article combines the author's personal experience of the border closure and reopening between France and Germany during the pandemic between March and June 2020, plus an analysis of French and German local and national press articles during this period, as well as the use of previous research results on European crises and borders, i.e. mainly those of a Jean Monnet network led by the University of Victoria on migration and border policies (2016-2018) and a Jean Monnet project on EU crises and border regions (2018-2021).

\section{Works Cited}

Bartel, Anja, Catherine Delcroix, and Elise Pape. 2020. "Refugees and the Dublin Convention: A Biographical Evaluation of Inner European Borders". Borders in Globalization Review 1(2): 40-52. https://doi.org/10.18357/bigr12202019589

BBC News. 2020. "Coronavirus: Trump suspends travel from Europe to US" (March 12). Available: https://www.bbc. com/news/world-us-canada-51846923

Beaupré, Claude, and Franziska Fischer. 2020. "The Label 'Refugee' and its Impacts on Border Policies". Borders in Globalization Review 1(2): 71-83. https://doi.org/10.18357/ bigr12202019562

Beck, Joachim. 2020. "Witness", Eprouver les frontières au temps de la COVID-19 Grenzfragen zur Zeit von COVID-19, Webinaire, Centre Jean-Monnet Franco-Allemand, 25.6.2020, available: centre-jean-monnet.unistra.fr

Berrod, Frédérique. 2020. "The Schengen Crisis and the EU's Internal and External Borders: A Step Backwards for Security-Oriented Migration Policy?" Borders in Globalization Review 1(2): 53-63. https://doi.org/10.18357/ bigr12202019602

Berrod, Frédérique, Morgane Chovet, and. Birte Wassenberg. 2020. "La Frontière Franco-Allemande Au Temps Du Covid-19: La Fin d'un Espace Commun?" The Conversation (April 16). Available: https://theconversation. com/la-frontiere-franco-allemande-au-temps-du-covid19-la-fin-dun-espace-commun-136467 
Boucart, Théo. 2020 '“Weg mit den Grenzen', 'Schengen 2.0': Quand l'engagement citoyen transcende la fermeture des frontières", Le Taurillon (June 17). Available: https://www. taurillon.org/weg-mit-den-grenzen-schengen-2-O-quandI-engagement-citoyen-transcende-la

Bouveresse, Aude. 2020. "The Ambiguous Relationship Between the EU and its Internal Borders: The European Citizen's Point of View". Borders in Globalization Review 1(2): 64-70. https://doi.org/10.18357/bigr12202019567

Brunet-Jailly, Emmanuel, and Birte Wassenberg. 2020. "Introduction: Comparing and Contrasting EU Border and Migration Policy-Are they Exemplary?" Borders in Globalization Review 1(2): 23-29. https://doi.org/10.18357/ bigr12202019793

"Castle Talks on Cross-Border Cooperation The migration crisis A humanitarian challenge for border regions", Program, Jean Monnet Project, March 16-17 2020. Available: centrejean-monnet.unistra.fr

Denni, K. 2008. Rheinüberschreitungen-Grenzüberwindungen. Die Grenze zwischen Frankreich und Deutschland (18612006). Munich: UVK.

Dreosto, Luc. 2020. "Coronavirus: les appels se multiplient pour rouvrir les frontières entre la France et l'Allemagne", France Bleu (May 9). Available: https://www.francebleu.fr/infos/ societe/coronavirus-les-appels-se-multiplient-pour-rouvrirles-frontieres-entre-la-france-et-l-allemagne-1589010306

Dernières Nouvelles d'Alsace [DNA]. 2020. "Kehl: des parapluies en signe d'amitié" (May 5). Available: https://www.dna.fr/edition-strasbourg/2020/05/10/ des-parapluies-en-signe-d-amitie

eurojournalist. 2020. "L'accueil de patients alsaciens dans le Bade-Wurtemberg a commencé" (March 21). Available: http://eurojournalist.eu/laccueil-de-patients-alsaciensdans-le-bade-wurtemberg-a-commence/
Le Parisien. 2020. "Coronavirus: 48 malades du Grand Est évacués en train vers le Sud-Ouest ce week-end", Le Parisien (March 27). Available: https://www. leparisien.fr/societe/sante/coronavirus-48-maladesdu-grand-est-evacues-en-train-vers-le-sud-ouest-ceweek-end-27-03-2020-8289546.php

Les Echos. 2020. La "réouverture des frontières avec l'Allemagne accueillie avec soulagement" (June 17).

Macron, Emmanuel. 2020. "Nous sommes en guerre': le verbatim du discours d'Emmanuel Macron". Le Monde (March 16). Available: https://www.lemonde.fr/politique/ article/2020/03/16/nous-sommes-en-guerre-retrouvezle-discours-de-macron-pour-lutter-contre-le-coronavirus_6033314_823448.html

Merkel, Angela. 2020. "Address to the nation". Die Bundeskanzlerin (March 18). Available: https://www. bundesregierung.de/breg-de/themen/coronavirus/-thisis-a-historic-task-and-it-can-only-be-mastered-if-weface-it-together--1732476

20 Minutes. 2020. "Coronavirus à Mulhouse: Des patients évacués par l'armée vers Toulon et Marseille" (March 18). Available: https://www.20minutes.fr/sante/274277120200318-coronavirus-mulhouse-patients-evacuesarmee-vers-toulon-marseille

Wassenberg, Birte. 2020a. "The Schengen Crisis and the End of the Myth of 'Europe without Borders'”. Borders in Globalization Review 1(2): 30-39. https://doi.org/10.18357/ bigr12202019599

Wassenberg, Birte. 2020b. "Witness", Eprouver les frontières au temps de la COVID-19 Grenzfragen zur Zeit von COVID-19, Webinaire, Centre Jean-Monnet Franco-Allemand (June 25). Available: centre-jean-monnet.unistra.fr 